\title{
Erkeklerin Toplumsal Cinsiyet Rollerine İlişkin Tutumları
}

\author{
Dr. Öğr. Üyesi İslam Can \\ Selçuk Üniversitesi Ali Akkanat Uygulamalı \\ Bilimler Yüksekokulu \\ islamcan@hotmail.com
}

\author{
Dr. Öğr. Üyesi Çă̆la Girgin Büyükbayraktar \\ Selçuk Üniversitesi Ali Akkanat Uygulamalı Bilimler \\ Yüksekokulu \\ cagla.girgin@hotmail.com
}

\section{Öz}

$\mathrm{Bu}$ çalışmanın amacı, erkeklerin toplumsal cinsiyet rollerine ilişkin tutumlarını farklı açılardan değerlendirmektir. Araştırmanın çalışma grubunu Konya ilinde ikamet etmekte olan basit seçkisiz örnekleme yoluyla seçilmiş 201 erkek oluşturmaktadır. Erkeklerin yaşlara göre dağılımları, 18-25 yaş aralığında 54 kişi (\%26.9), 26-40 yaş aralığında 59 kişi (\%29.4), 4155 yaş aralığında 47 kişi (\%23.4) ve 56 yaş ve üzerinde 41 kişi (\%20.4) şeklindedir. Araştırmada veri toplama yöntemi olarak kişisel bilgi formu ve toplumsal cinsiyet rolü tutum ölçeğini içeren anket formu kullanılmıştır. Kişisel bilgi formu araştırmacılar tarafından hazırlanmış olup, toplumsal cinsiyet rolleri tutum ölçeği 2011 yılında ZeyneloğluTerzioğlu tarafından geliştirilmiş ve toplam 38 maddeden oluşan bir ölçektir. Araştırmadan elde edilen verileri analiz etmek için frekans analizi ve ANOVA yöntemleri kullanılmıştır. Elde edilen bulgular, erkeklerin toplumsal cinsiyet tutumları ile yaşları arasındaki farklılıkların, erkek cinsiyet rolü hariç, tüm alt boyutlarda anlamlı olduğunu göstermektedir. Toplumsal cinsiyet rollerine ilişkin tutumları ile eğitim düzeyleri arasındaki farklılıklara bakıldığında, toplumsal cinsiyet rolleri tutumu eğitim düzeyine göre tüm alt boyutlarda anlamlı bulunmuştur. Toplumsal cinsiyet rolleri tutumları ile evlenme şekli arasındaki farklılıklara bakıldığında, elde edilen sonuçlara göre toplumsal cinsiyet rolleri tutumu evlenme şekline geleneksel cinsiyet rolü ve erkek cinsiyet rolü hariç tüm alt boyutlarda anlamlı bulunmuştur. Toplumsal cinsiyet rolleri tutumu dinin duyguları ve düşünceleri etkileme oranına göre eşitlikçi cinsiyet rolü ve evlilikte cinsiyet rolü hariç tüm alt boyutlarda anlamlı bulunmuştur. Elde edilen sonuçlar ilgili literatür ışığında tartışılmıştır.

Anahtar Kelimeler: Toplumsal cinsiyet, cinsiyet rolleri, tutum, erkekler.

\section{Men's Attitudes Related to Gender Roles}

\section{Abstract}

The purpose of this study is to assess the attitudes of men towards gender roles from different perspectives. The study group of the research is composed of 201 men selected by simple random sampling residing in Konya province. The distribution of males according to their ages is like; 54 individuals (26.9\%) are in the age range of $18-25$ years, 59 individuals $(29.4 \%)$ are in the age range of $26-40$ years, 47 individuals (23.4\%) are in the age range of $41-$ 55 years, and 41 individuals $(20.4 \%)$ are 56 years and over. As a method of collecting data in the survey, a personal information form and a questionnaire form including the gender role attitude scale were used. The personal information form was prepared by the researchers 
and the gender role attitude scale was developed by Zeyneloğlu-Terzioğlu in 2011 and is a scale that consists of a total of 38 items. Frequency analysis and ANOVA methods were used to analyze the data obtained from the study. Findings indicate that differences between gender attitudes of males and their ages are significant in all subscales except for male gender role. Considering the differences between the attitudes towards gender roles and the levels of education, gender role attitude was found to be significant in all sub-dimensions compared to education level. When the differences between gender role attitudes and marriage patterns are examined, according to the obtained results, gender role attitude to marriage patterns was found to be significant in all sub-dimensions except for traditional gender role and male gender role. Gender role attitude was found to be significant in all subdimensions except for the egalitarian gender role and the sex role in marriage, according to the rate of religion affecting feelings and thoughts. The obtained results were discussed in the light of relevant literature.

Keywords: Gender, gender roles, attitude, males. 


\section{GİRIŞ}

Erkek ve kadınları birbirinden ayıran biyolojik farklılıklar, cinsiyet farklılıkları olarak bilinir. Bunlar; üreme görevleri, hormonlar ve anatomideki farklılıkları kapsar (GerrigZimbardo 2015: 327; Connell 1998a: 225; Sancar 2014: 23). Biyolojik cinsiyet genellikle biyolojik belirleyiciler kullanılarak tanımlanırken, toplumsal cinsiyet ise, toplumsal cinsiyete bağlı özellikler, stereotipler ve roller kullanılarak tanımlanır (Eagly-Wood 1999; Can 2013: 243). Cinsiyetler arasında davranış ve özellik farklılıkları konusunda insanların kalıplaşmış anlayış biçimleri vardır (Cüceloğlu 2006: 391; Onaran vd. 1998: 1). Cinsiyet kalıp yargılarını doğrular nitelikte cinsler arasındaki net ayrımları yansıtan pek az fiziksel ve psikolojik kanıt bulunmaktadır. Farklılıkların çoğu cinsiyet rollerinden kaynaklanır. Toplumsal cinsiyet rolleri ebeveynler, öğretmenler, medya, din gibi toplumdaki sosyalleştiriciler tarafından oluşturulur (Basow 1992; Connell 1998a). Bu kalıplaşmış anlayış biçimlerini açıklayan Bem'in (1981) toplumsal cinsiyet şeması teorisine göre cinsiyet rolü, biyolojik cinsiyete bakılmaksızın benlik konseptiyle tutarlı bir özellik gösterir. Toplumsal cinsiyet rolleri, toplumsal cinsiyete ilişkin şablonu temsil eden erkeklik ve kadınlık tanımlarını, kültürel bilgiyi kodlamak ve düzenlemek için hazır olan erkeklik ve kadınlığı ifade etmenin öğrenilmiş biçimleridir (Bem 1981; Onaran vd. 1998; Agacinski 1998: 16). Bir başka açıdan toplumsal cinsiyet, erkeklik ve dişiliğin toplumsal bir yapısıdır, normatif/kuralcı/örnek inançlar ve beklentilerle düzenlenen bir statüsüdür (Eisler-Blalock 1991; Segal 1992: 128). Küçük erkek ve kız çocukları büyüyüp erkek ve kadın olurken cinsiyet rolü denilen bir dizi davranışsal ve bilişsel kural öğrenirler (Onaran vd. 1998: 5; Segal 1992: 133). Dolayısıyla cinsiyet rolü, toplumun kadınların ve erkeklerin düşünme ve davranma şekli olarak belirlediği geleneksel ya da stereotipik davranış, tavır, değer ve kişilik özelliklerini tanımlar (Plotnik 2007: 418).

Güncel cinsiyet çalışmalarında temel toplumsal güç biçimleri ile ilişkili olan erkeklik, baskın olarak kendini hissettirmektedir (Connell 1998a: 226; Connell-Wood 2005; Agacinski 1998: 35; Sancar 2009, 2014). Cinsiyet rollerinin anlaşılması, dünya çapında erkekler ve erkeklik hakkında düşünmek için gerekli bir dayanaktır (Connell 1998b; Onaran vd. 1998; Sancar 2009). Toplumsal cinsiyet ideolojisi, kültürel normlar ve geleneklere, toplumsallaşma sürecine ve beklentilere dayanmaktadır (Dijkstra-Plantenga 1997; Wade 1996, Sancar 2014: 24-26). Toplumsal cinsiyet rolleri, bir sürecin zıt uçlarındaki erkeklik ve kadınlık olarak ikiye bölünerek kavramsallaştırılmıştır (Sancar 2014). Dahası, geleneksel görüş, psikolojik olarak sağlıklı olan erkeklerin ve kadınların cinsiyetlerine özgü değerler, tutumlar ve davranışları içselleştirdiklerini; yani "sağlıklı" bir erkeğin yararcı, saldırgan ve erkeksi, "sağlıklı" bir kadının ise etkileyici, sosyal ve kadınsı (Patterson- McCubbin 1984; Sancar 2009: 28-29) olma niteliklerinin doğasında var olduğunu öne sürer.

Ebeveynler, kendi inançlarını cinsiyetle açıkça ve gizlice paylaşmaktadır (Onaran vd. 1998: 10-11). Ebeveyn etkisinin toplumsal cinsiyet rolünün gelişimi üzerindeki etkisine ilişkin bu genel bakış, cinsiyete dayalı rollerin yönlendirilmesinin, geleneksel cinsiyet rollerine sıkıca bağlı olmaktan çok, çocuklara faydalı olabileceği fikrini ortaya çıkarmaktadır (Witt 1997). Bunun yanı sıra cinsiyet rolü tutumlarının önemli bir bölümü, kadınların ailedeki rolleriyle ilgilidir. Aile ile ilgili cinsiyet rolleri, kadınların yerel ve kamusal alanlar arasındaki tercihlerini ve bu alanlardaki işlevleri etkilemektedir (Liao-Cai 1995; Çelebi 1990). Aileye ve toplumsal cinsiyet rollerine yönelik tutumlarda bireyler arasında önemli farklılıklar vardır. Bu bağlamda cinsiyete, aileye ve toplumsal cinsiyet rollerine yönelik daha geleneksel veya daha alışılmadık tutumlarla ilişkili bireysel özellikleri belirlemek önemlidir 
(Lye-Waldron 1997). Geleneksel cinsiyet rolü tutumları, erkeğin evi geçindiren kişi, kadının ise ev hanımı-anne rolünü vurgular. Geleneksel olmayan tutumlar ise, bunun aksine, paylaşılan rolleri ve eşitlikçiliği vurgular (Amato-Booth 1995; Çelebi 1990). Erkek rolüyle ilgili geleneksel tutumlar düşünüldügünde, duyguları ifade etme konusundaki endişelerin ve diğerlerine karşı duygulanımın dile getirilmesiyle ilgili kaygıların ortak noktalar olduğu görülmektedir (Good-Dell-Mintz 1989; Addis-Mahalik 2003). Mahalik- Cournoyer-DeFrancCherry-Napolitano (1998) 'nin yaptıkları araştırmanın sonuçlarına göre erkeklerin başarılı olma, güçlü ve rekabetçi olma konusunda daha fazla katı oldukları ortaya çıkmıştır; duyguları ifade etme ve diğerlerine duyulan sevgiyi ifade etme konusunda ise olgunlaşmamış ve nevrotik psikolojik savunma mekanizması kullandıkları görülmüştür.

Son yirmi yılda aile hayatındaki önemli değişimlerden biri, kadın ve erkek rollerinin değişmesidir. Kocanın tek işçi olduğu ev ve çocuk bakımının sorumluluğunun kadında olduğu geleneksel evliliklerin aksine kadınlar, giderek aynı anda eş, anne ve işçi rollerinde hareket etmektedir (Durak-Şenol-Durak vd. 2016: 247; Onaran vd 1998: 19-22; Sancar 2014; Çelebi 1990). Buradan hareketle eğer tutumlar, cinsiyetler arasında önemli farklılıklar gösteriyorsa, bu farklılıklar hayatın ileriki aşamalarında da çatışmalara sebep olabilir (Mensch-Ibrahim vd. 2003). İnsanların günlük yaşantılarının neredeyse her yönünü etkileyen toplumsal cinsiyet rolleri (Bussey-Bandura 1999; Sancar 2009), kuşkusuz üzerinde çalışılması gereken önemli bir konudur. Diğer taraftan erkeklerin toplumsal cinsiyet rollerine ilişkin geleneksel bakış açıları, toplumda kadınların statüsünü etkilemektedir (Vefikuluçay-Zeyneloğlu vd. 2007; Agacinski 1998; Çelebi 1990). Ancak literatürde yer alan toplumsal cinsiyet rolü tutumları ile ilgili yapılan çalışmalara ele alındığında, erkekler üzerinde kadınlara kıyasla daha az araştırma yapıldığg görülmektedir (Cassidy-Warren 1996; Blee-Tickamyer 1995; Onaran vd. 1998; Sancar 2009: 23). Bu anlamda literatüre katk1 yapmak olan bu çalışmanın amacı, erkeklerin toplumsal cinsiyet rollerine ilişkin tutumlarını farklı açlardan değerlendirmektir. Bu amaç doğrultusunda aşağıdaki sorulara yanıt aranmıştır:

1-Erkeklerin toplumsal cinsiyet rollerine ilişkin tutumları, yaşa göre anlamlı düzeyde farklılaşmakta mıdır?

2-Erkeklerin toplumsal cinsiyet rollerine ilişkin tutumları, eğitim düzeyine göre anlamlı düzeyde farklılaşmakta mıdır?

3-Erkeklerin toplumsal cinsiyet rollerine ilişkin tutumları, evlilik şekline göre anlamlı düzeyde farklılaşmakta mıdır?

4- Erkeklerin toplumsal cinsiyet rollerine ilişkin tutumları, dinin duygu ve düşünceleri etkilemesine göre anlamlı düzeyde farklılaşmakta mıdır?

\section{YÖNTEM}

\section{Araştırmanın Modeli}

Bu çalışma, ilişkisel tarama modelinde gerçekleştirilmiştir. Sosyal bilimlerde yaygın olarak kullanılan tarama araştırmaları, geniş gruplar üzerinde yürütülen gruptaki bireylerin, bir olgu ve olayla ilgili olarak görüşlerinin, tutumlarının alındığı, olgu ve olayların betimlenmeye çalışıldığı araştırmalardır (Karakaya 2014: 59). İlişkisel tarama ise, değişkenler arasındaki ilişkileri saptamak için yapılan çalışmalardır (Sönmez-Alacapınar 2017: 50). 


\section{Çalışma Grubu}

Araştırmanın çalışma grubu, Konya ilinde yaşayan, gönüllü olarak çalışmaya katılmak isteyen, basit seçkisiz örnekleme yoluyla seçilmiş $201 \quad(\mathrm{~N}=201)$ erkekten oluşmaktadır. Erkeklerin sosyo-demografik özelliklerine göre; dağılımlarına bakıldığında, 18-25 yaş aralığında 54 kişi (\%26.9), 26-40 yaş aralığında 59 kişi (\%29.4), 41-55 yaş aralığında 47 kişi (\%23.4) ve 56 yaş ve üzerinde 41 kişi (\%20.4) olduğu görülmektedir. Aylık gelirlerine göre; 0-1500 TL aralığında 29 kişi (\%14.4), 1501-3000 TL aralığında 82 kişi (\%40.8), 3001-4500 TL aralığında 48 kişi (\%23.9) ve 4501 TL ve üzerinde ise, 42 kişi (\%20.9) bulunmaktadır. Medeni durumlarına göre; evli olanlar 123 kişi (\%61.2), hiç evlenmemiş olanlar 69 kişi(\%34.3), eşi ölmüş olanlar 5 kişi (\%2.5) ve boşanmış olanlar ise, 4 kişi (\%2) olarak dağılmaktadır. Eğitim durumlarına göre; okur-yazar olmayanlar 2 kişi (\%1), okur-yazar olanlar 13 kişi (\%6.5), ilkokul mezunu olanlar 37 kişi (\%18.4), ortaokul mezunu olanlar 13 kişi (\%6.5), lise mezunu olanlar 37 kişi (\%18.4), yüksekokul/üniversite mezunu olanlar 85 kişi (\%42.3) ve lisansüstü mezunu olanlar ise, 14 kişi (\%7)'dir. Mesleklere göre dağılımlarına bakıldığında, eğitimci 17 kişi (\%8.5), esnaf/işletmeci 36 kişi(\%17.9), memur 13 kişi (\%6.5), çiftçi 11 kişi (\%5.5), sağlık hizmetleri çalışanı 4 kişi(\%2), öğrenci 44 kişi (\%21.9), emekli 25 kişi (\%12.4) ve işçi 44 kişi (\%21.9), diğer kategorisinde yanıt verenler ise, 7 kişi (\%3.5)'dir. Hayatının çoğunu geçirdiği yerleşim yerine göre; büyükşehir(il) 98 kişi (\%48.8), şehir (il) 43 kişi(\%21.4), ilçe 39 kişi (\%19.4) ve köy-kasaba ise, 21 kişi (\%10.4)'dir. Aile içindeki konuma göre; baba 56 kişi (\%27.9), evin reisi 45 kişi (\%22.4), koca/eş 16 kişi (\%8), evin çocuğu 24 kişi (\%11.9), evin erkeği 12 kişi (\%6), dede/büyükbaba 9 kişi (\%4.5), evin oğlu 36 kişi (\%17.9) ve diğer kategorisinde yanıt verenler ise, 3 kişi (\%1.5) olarak dağılmaktadır. "Din duygu ve düşüncelerinizi ne oranda etkilemektedir." Sorusuna verilen yantlara göre; "din, duygu ve düşüncelerimi büyük oranda etkiler" şeklinde yanit verenler 128 kişi (\%63.7), "din, duygu ve düşüncelerimi az etkiler" yanıtını verenler 61 kişi (\%30.3), "din, duygu ve düşüncelerimi hiç etkilemez" şeklinde yanıt verenler 9 kişi (\%4.5), "dine inanmıyorum" şeklinde yanıt verenler ise, 3 kişi (\%1.5)'dir. Evlilik süresine göre; 0-3 yıl arasında 12 kişi (\%6), 4-6 yıl arasında 12 kişi (\%6), 7-9 yıl arasında 76 kişi (\%37.8) ve 10 yıl ve üzerinde ise, 101 kişi (\%50.2) yer almaktadır. Evlilik yaşına göre; 16-20 yaş arasında evlenenler 20 kişi (\%10), 21-25 yaş arasında evlenenler 67 kişi (\%33.3), 26-30 yaş arasında evlenenler 107 kişi (\%53.2) ve 31 yaş ve üzerinde evlenenler ise, 7 kişi (\%3.5)'dir. Evlilik şekline göre; severek/flört ederek evlenenler 45 kişi (\%22.4), görücü usulü/isteyerek evlenenler 82 kişi (\%40.8), görücü usulü/istemeyerek evlenenler ise, 74 kişi (\%36.8)'dir. Çocuk sayısına göre; 1 çocuğu olanlar 13 kişi (\%6.5), 2 çocuğu olanlar 41 kişi (\%20.4), 3 çocuğu olanlar 46 kişi (\%22.9) ve 4 ve üzerinde çocuğu olanlar 24 kişi (\%11.9) ve çocuğu olmayanlar ise, 77 kişi (\%38.3)'dir.

Tablo 1. Sosyo-Demografik Veriler

\begin{tabular}{|l|l|l|l|l|l|}
\hline Yaş & $\mathbf{N}$ & $\mathbf{\%}$ & $\begin{array}{l}\text { Hayatın Çoğunun } \\
\text { Geçirildiği Yerleşim } \\
\text { Yeri }\end{array}$ & $\mathbf{N}$ & $\mathbf{\%}$ \\
\hline $18-25$ & 54 & 26.9 & Büyükşehir(il) & 98 & 48.8 \\
\hline $26-40$ & 59 & 29.4 & Şehir(il) & 43 & 21.4 \\
\hline $41-55$ & 47 & 23.4 & İçe & 39 & 19.4 \\
\hline 56 ve üzeri & 41 & 20.4 & Köy-Kasaba & 21 & 10.4 \\
\hline Aylkk Gelir & $\mathbf{N}$ & $\mathbf{\%}$ & Aile içindeki Konum & $\mathbf{N}$ & $\%$ \\
\hline $0-1500$ TL & 29 & 14.4 & Baba & 56 & 27.9 \\
\hline
\end{tabular}

SEFAD, 2018 (39): 355-372 


\begin{tabular}{|c|c|c|c|c|c|}
\hline 1501-3000TL & 82 & 40.8 & Evin Reisi & 45 & 22.4 \\
\hline 3001-4500TL & 48 & 23.9 & Koca/Eş & 16 & 8 \\
\hline 4501 ve üzeri & 42 & 20.9 & Evin çocuğu & 24 & 11.9 \\
\hline Medeni Durum & $\mathbf{N}$ & $\%$ & Evin erkeği & 12 & 6 \\
\hline Evli & 123 & 61.2 & Dede/büyükbaba & 9 & 4.5 \\
\hline Hiç Evlenmemiş & 69 & 34.3 & Evin oğlu & 36 & 17.9 \\
\hline Eşi Ölmüş & 5 & 2.5 & Diğer & 3 & 1.5 \\
\hline Boşanmış & 4 & 2.0 & $\begin{array}{lr}\text { Din Duygu ve } & \text { ve } \\
\text { düşüncelerinizi } & \text { ne } \\
\text { oranda etkilemektedir }\end{array}$ & $\mathbf{N}$ & $\%$ \\
\hline Eğitim Durumu & $\mathbf{N}$ & $\%$ & Büyük oranda & 128 & 63.7 \\
\hline Okur-Yazar Değil & 2 & 1 & Az etkiler & 61 & 30.3 \\
\hline Okur-Yazar (İlkokul terk vb.) & 13 & 6.5 & Hiç etkilemez & 9 & 4.5 \\
\hline İlkokul & 37 & 18.4 & İnanmiyorum & 3 & 1.5 \\
\hline Ortaokul & 13 & 6.5 & Evlilik Süresi & $\mathbf{N}$ & $\%$ \\
\hline Lise & 37 & 18.4 & $0-3$ yıl & 12 & 6 \\
\hline Yüksekokul/Üniversite & 85 & 42.3 & $4-6$ yil & 12 & 6 \\
\hline $\begin{array}{lll}\begin{array}{l}\text { Lisansüstü (Yüksek Lisans, } \\
\text { Doktora) }\end{array} & & \\
\end{array}$ & 14 & 7 & $7-9$ yil & 76 & 37.8 \\
\hline Meslek & $\mathbf{N}$ & $\%$ & 10 ve üzeri & 101 & 50.2 \\
\hline $\begin{array}{l}\text { Eğitimci (Öğretmen, Öğretim } \\
\text { üyesi vd.) }\end{array}$ & 17 & 8.5 & Evlilik Yaşı & $\mathbf{N}$ & $\%$ \\
\hline Esnaf/İşletmeci & 36 & 17.9 & $16-20$ yaş & 20 & 10 \\
\hline Memur & 13 & 6.5 & $21-25$ yaş & 67 & 33.3 \\
\hline Çiftçi & 11 & 5.5 & $26-30$ yaş & 107 & 53.2 \\
\hline $\begin{array}{ll}\text { Sağllk } & \text { Hizmetleri } \\
\text { (Hekim/Hemşire vd.) }\end{array}$ & 4 & 2 & 31-yaş ve üzeri & 7 & 3.5 \\
\hline $\begin{array}{l}\text { Öğrenci } \\
\text { (Önlisans/Lisans/Lisansüstü) }\end{array}$ & 44 & 21.9 & Çocuk Sayısı & $\mathbf{N}$ & $\%$ \\
\hline Emekli & 25 & 12.4 & 1 & 13 & 6.5 \\
\hline İşçi (Özel ya da Kamuda) & 44 & 21.9 & 2 & 41 & 20.4 \\
\hline Diğer & 7 & 3.5 & 3 & 46 & 22.9 \\
\hline Evlenme Şekli & $\mathbf{N}$ & $\%$ & 4 ve üzeri & 24 & 11.9 \\
\hline Severek/Flört Ederek & 45 & 22.4 & Çocuğum yok & 77 & 38.3 \\
\hline Görücü Usulü/ İsteyerek & 82 & 40.8 & & & \\
\hline Görücü Usulü/İstemeyerek & 74 & 36.8 & Toplam & 201 & 100 \\
\hline
\end{tabular}

\section{Veri Toplama Araçları}

Araştırmada kişisel bilgi formu ve toplumsal cinsiyet rolleri tutum ölçeğini oluşan bir anket formu katılımcılara uygulanmıştır. 


\section{Toplumsal Cinsiyet Rolleri Tutum Ölçeği}

Toplumsal Cinsiyet Rolleri Tutum Ölçeği, üniversite öğrenimi gören öğrencilerin toplumsal cinsiyet rollerine ilişkin tutumlarını belirlemek amacıyla 2011 yılında ZeyneloğluTerzioğlu tarafından geliştirilmiştir. Toplam 38 maddeden oluşan Toplumsal Cinsiyet Rolleri Tutum Ölçeği, 0-5 arası puanlanmaktadır. Ölçek, öğrenciler toplumsal cinsiyet rollerine ilişkin eşitlikçi tutum cümlelerine göre; tamamen katılıyorsa " 5 " puan, katılıyorsa "4" puan, kararsizsa "3" puan, katılmiyorsa "2" puan, kesinlikle katılmiyorsa "1" puan alacak şekilde puanlandırılmıştır. Toplumsal cinsiyet rollerine ilişkin geleneksel tutum cümleleri ise; yukarıda belirtilen puanlamanın tam tersi olarak, öğrenciler tamamen katılıyorsa "1" puan, katıliyorsa"2" puan, kararsizsa "3" puan, katılmiyorsa " 4 " puan, kesinlikle katılmıyorsa " 5 " puan alacak şekilde puanlandırılmıştır. Bu puanlama şekli ile ölçekten alınabilecek en yüksek puan 190; en düşük puan ise, 38 olarak hesaplanmıştır. Ölçekten alınan en yüksek değer, öğrencinin toplumsal cinsiyet rollerine ilişkin eşitlikçi tutuma sahip olduğunu, en düşük değer ise öğrencinin toplumsal cinsiyet rollerine ilişkin geleneksel tutuma sahip olduğunu göstermektedir. Toplumsal Cinsiyet Rolleri Tutum Ölçeğinin Cronbach Alfa Güvenirlik Katsayısı 38 madde için "0.92" olarak bulunmuştur. Bu sonuç, ölçek maddelerinin birbiriyle yüksek iç tutarlılığa ve yüksek güvenirliğe sahip olduğunu göstermektedir (Zeyneloğlu- Terzioğlu 2011).

\section{İșlem}

Veriler Konya ilinde ikamet etmekte olan, gönüllü olarak çalışmaya katılmak isteyen erkekler arasında basit seçkisiz örnekleme yoluyla seçilmiş erkeklerden elde edilmiştir. Kişisel bilgi formu ve toplumsal cinsiyet rolleri tutum ölçeğinin bulunduğu batarya erkeklere dağıtılmış ve uygulamaları yaklaşık 35 dakika sürmüştür. Veriler SPSS 21 Paket programı kullanılarak analiz edilmiştir.

Erkeklerin toplumsal cinsiyet rolleri ile yaş, eğitim düzeyi, evlilik şekli ve din ile ilgili düşünceleri arasındaki ilişkinin belirlenmesi amacıyla tek yönlü varyans analizi (one-way ANOVA) yapılmıştır. İlişkisiz üç ya da daha fazla örneklemin ortalamaları arasındaki farkın anlamlılı̆̆ını belirlemede bu analiz kullanılır (Ekiz 2017:150).

\section{BULGULAR}

$\mathrm{Bu}$ bölümde alt amaçlarla ilgili bulgulara yer verilmiştir. Aşağıda erkeklerin toplumsal cinsiyet rollerinin yaşa, eğitim düzeyine, evlilik şekline ve dini referansa göre anlamlı düzeyde farklılaşıp farklılaşmadığına ilişkin bulgular yer almaktadır.

Tablo 2. Toplumsal Cinsiyet Rolleri Alt Boyutlarının Yaşa Göre ANOVA Sonuçları

\begin{tabular}{|c|c|c|c|c|c|c|c|}
\hline Boyutlar & $\begin{array}{l}\text { Yaş } \\
\text { Değişkeni }\end{array}$ & $\mathbf{N}$ & $x$ & Ss & $\mathbf{F}$ & p & Anlam \\
\hline \multirow{4}{*}{$\begin{array}{l}\text { Eşitlikçi } \\
\text { Cinsiyet Rolü }\end{array}$} & $18-25$ & 54 & 33,76 & 4,13 & \multirow{4}{*}{5,241} & \multirow{4}{*}{, $002^{*}$} & \multirow{4}{*}{$\begin{array}{l}\text { 18-25/41-55 } \\
18-25 / 56 \text { ve } \\
\text { üzeri }\end{array}$} \\
\hline & $26-40$ & 59 & 31,98 & 4,61 & & & \\
\hline & $41-55$ & 47 & 30,62 & 5,17 & & & \\
\hline & 56 ve üzeri & 41 & 30,20 & 6,03 & & & \\
\hline \multirow{3}{*}{$\begin{array}{l}\text { Kadın Cinsiyet } \\
\text { Rolü }\end{array}$} & $18-25$ & 54 & 21,70 & 6,41 & \multirow{3}{*}{6,490} & \multirow{3}{*}{, $000^{*}$} & \multirow{3}{*}{$\begin{array}{l}\text { 18-25/41-55 } \\
18-25 / 56 \text { ve } \\
\text { üzeri }\end{array}$} \\
\hline & $26-40$ & 59 & 19,68 & 5,58 & & & \\
\hline & 41-55 & 47 & 18,17 & 5,95 & & & \\
\hline
\end{tabular}

SEFAD, 2018 (39): 355-372 


\begin{tabular}{|c|c|c|c|c|c|c|c|}
\hline & 56 ve üzeri & 41 & 16,56 & 5,78 & & & $\begin{array}{l}26-40 / 56 \text { ve } \\
\text { üzeri }\end{array}$ \\
\hline \multirow{4}{*}{$\begin{array}{l}\text { Evlilikte } \\
\text { Cinsiyet Rolü }\end{array}$} & $18-25$ & 54 & 31,61 & 5,18 & \multirow{4}{*}{4,405} & \multirow{4}{*}{, $005^{*}$} & \multirow{4}{*}{$\begin{array}{l}18-25 / 56 \text { ve } \\
\text { üzeri }\end{array}$} \\
\hline & $26-40$ & 59 & 30,31 & 3,72 & & & \\
\hline & $41-55$ & 47 & 29,19 & 5,23 & & & \\
\hline & 56 ve üzeri & 41 & 28,10 & 5,80 & & & \\
\hline \multirow{4}{*}{$\begin{array}{l}\text { Geleneksel } \\
\text { Cinsiyet Rolü }\end{array}$} & $18-25$ & 54 & 21,37 & 5,82 & \multirow{4}{*}{2,561} & \multirow{4}{*}{, $056^{*}$} & \multirow{4}{*}{$\begin{array}{l}18-25 / 41-55 \\
18-25 / 56 \text { ve } \\
\text { üzeri }\end{array}$} \\
\hline & $26-40$ & 59 & 20,00 & 5,47 & & & \\
\hline & 41-55 & 47 & 18,79 & 5,99 & & & \\
\hline & 56 ve üzeri & 41 & 18,39 & 6,35 & & & \\
\hline \multirow{4}{*}{$\begin{array}{l}\text { Erkek Cinsiyet } \\
\text { Rolü }\end{array}$} & $18-25$ & 54 & 21,80 & 4,47 & \multirow{4}{*}{1,783} & \multirow{4}{*}{,152 } & \multirow{4}{*}{ - } \\
\hline & $26-40$ & 59 & 20,80 & 4,09 & & & \\
\hline & 41-55 & 47 & 21,43 & 4,33 & & & \\
\hline & 56 ve üzeri & 41 & 19,80 & 4,81 & & & \\
\hline \multirow{4}{*}{$\begin{array}{l}\text { Toplam } \\
\text { Cinsiyet Rolü }\end{array}$} & $18-25$ & 54 & 130,26 & 19,05 & \multirow{4}{*}{6,952} & \multirow{4}{*}{, $000^{*}$} & \multirow{4}{*}{$\begin{array}{l}18-25 / 41-55 \\
18-25 / 56 \text { ve } \\
\text { üzeri }\end{array}$} \\
\hline & $26-40$ & 59 & 122,76 & 15,42 & & & \\
\hline & $41-55$ & 47 & 118,19 & 20,42 & & & \\
\hline & 56 ve üzeri & 41 & 113,05 & 22,51 & & & \\
\hline
\end{tabular}

$\left(^{*}\right)$ işareti farkın anlamlı olduğunu göstermektedir; $\mathrm{p}<0.05$

(-) işareti farkın anlamlı olmadığını göstermektedir; $p>0.05$

Tablo. 2 incelendiğinde, erkeklerin toplumsal cinsiyet rollerine ilişkin tutumları ile yaşları arasındaki farklılıklar gözlenmektedir. Eşitlikçi cinsiyet rolü alt boyutunda, 18-25 yaş arası erkeklerin aritmetik ortalamaları 33.76, 26-40 yaş arası erkeklerin aritmetik ortalamaları $31.98,41-55$ yaş arası erkeklerin aritmetik ortalamaları 30.62, 56 yaş ve üzerindeki erkeklerin aritmetik ortalamaları 30.20'dir. Kadın cinsiyet rolünde ise, 18-25 yaş arası erkeklerin aritmetik ortalamaları 21.70, 26-40 yaş arası erkeklerin aritmetik ortalamaları 19.68, 41-55 yaş arası erkeklerin aritmetik ortalamaları 18.17, 56 yaş ve üzerindeki erkeklerin aritmetik ortalamaları $16.56^{\prime}$ dır. Evlilikte cinsiyet rolü alt boyutunda, 18-25 yaş arası erkeklerin aritmetik ortalamaları 31.61, 26-40 yaş arasındaki erkeklerin aritmetik ortalamaları 30.31, 4155 yaş arasındaki erkeklerin aritmetik ortalamaları 29.19, 56 ve üzerinde erkeklerin aritmetik ortalamaları 28.10 'dur. Geleneksel cinsiyet rolü alt boyutuna göre, 18-25 yaş arası erkeklerin aritmetik ortalamaları 21.37, 26-40 yaş 20.00, 41-55 yaş 18.79, 56 ve üzeri 18.39 'dır. Erkek cinsiyet rolü alt boyutunda, 18-25 yaş arasının aritmetik ortalaması 21.80, 26-40 yaş arasının aritmetik ortalaması 20.80, $41-55$ yaş arası 21.43 ve 56 yaş ve üzerinin aritmetik ortalaması ise 19.80 'dir.Toplumsal cinsiyet rolü toplam puana göre, $18-25$ yaş arasının aritmetik ortalaması 130.26, 26-40 yaş arasının 122.76, 41-55 yaş arasının 118.19, 56 yaş ve üzerinin aritmetik ortalaması ise, 113.05 'dir.Eşitlikçi cinsiyet rolü alt boyutunda hesaplanan F değeri " 5.241 " $(\mathrm{p}<0.05)$, kadın cinsiyet rolü alt boyutunda hesaplanan F değeri “6.490” $(\mathrm{p}<0.05)$, evlilikte cinsiyet rolü alt boyutunda hesaplanan F değeri "4.405" ( $p<0.05)$, geleneksel cinsiyet rolü alt boyutunda hesaplanan F değeri “2.561" ( $\mathrm{p}<0.05)$, erkek cinsiyet rolü alt boyutunda hesaplanan F değeri "1.783" ( $\mathrm{p}>0.05)$, toplumsal cinsiyet rolü toplam puanda hesaplanan F değeri ise, "6.952" $(\mathrm{p}<0.05)$ 'dir. Sonuçlara göre toplumsal cinsiyet rolleri tutumu erkek cinsiyet rolü hariç $(\mathrm{F}=1.783, \mathrm{p}>0.05)$ tüm alt boyutlarda anlamlı bulunmuştur. 
Tablo 3. Toplumsal Cinsiyet Rolleri Alt Boyutlarının Eğitim Düzeyine Göre ANOVA Sonuçları

\begin{tabular}{|c|c|c|c|c|c|c|c|}
\hline Boyutlar & Eğitim Düzeyi & $\mathbf{N}$ & $x$ & ss & $\mathbf{F}$ & $\mathbf{P}$ & $\begin{array}{l}\text { Anlam } \\
\text { (Scheffe } \\
\text { Testi) }\end{array}$ \\
\hline \multirow{7}{*}{$\begin{array}{l}\text { Eşitlikçi } \\
\text { Cinsiyet } \\
\text { Rolü }\end{array}$} & Okur-yazar değil & 2 & 30,50 & 10,61 & \multirow{7}{*}{2,178} & \multirow{7}{*}{, $047^{*}$} & \multirow{7}{*}{$\begin{array}{l}\text { İlkokul- } \\
\text { Yüksekokul }\end{array}$} \\
\hline & Okur-yazar & 13 & 30,31 & 7,67 & & & \\
\hline & İlkokul & 37 & 30,09 & 4,56 & & & \\
\hline & Ortaokul & 13 & 31,08 & 4,91 & & & \\
\hline & Lise & 37 & 31,00 & 5,12 & & & \\
\hline & Yüksekokul/Üniversite & 85 & 33,14 & 4,58 & & & \\
\hline & $\begin{array}{ll}\text { Lisansüstü } & \text { (YL- } \\
\text { Doktora) } & \\
\end{array}$ & 14 & 32,29 & 4,91 & & & \\
\hline \multirow{7}{*}{$\begin{array}{l}\text { Kadın } \\
\text { Cinsiyet } \\
\text { Rolü }\end{array}$} & Okur-yazar değil & 2 & 14,50 & 6,36 & \multirow{7}{*}{6,231} & \multirow{7}{*}{, $000^{*}$} & \multirow{7}{*}{$\begin{array}{l}\text { İlkokul- } \\
\text { Lise } \\
\text { İlkokul- } \\
\text { Yüksekokul } \\
\text { Okuryazar- } \\
\text { Yüsekokul }\end{array}$} \\
\hline & Okur-yazar & 13 & 16,15 & 4,81 & & & \\
\hline & İlkokul & 37 & 16,22 & 5,19 & & & \\
\hline & Ortaokul & 13 & 15,85 & 4,91 & & & \\
\hline & Lise & 37 & 18,92 & 5,45 & & & \\
\hline & Yüksekokul/Üniversite & 85 & 21,84 & 6,24 & & & \\
\hline & $\begin{array}{l}\text { Lisansüstü } \quad(Y L- \\
\text { Doktora) }\end{array}$ & 14 & 18,93 & 6,09 & & & \\
\hline \multirow{7}{*}{$\begin{array}{l}\text { Evlilikte } \\
\text { Cinsiyet } \\
\text { Rolüi }\end{array}$} & Okur-yazar değil & 2 & 27,50 & 4,95 & \multirow{7}{*}{5,597} & \multirow{7}{*}{, $000^{*}$} & \multirow{7}{*}{$\begin{array}{l}\text { İlkokul- } \\
\text { Yüksekokul } \\
\text { Ortaokul- } \\
\text { Yüsekokul }\end{array}$} \\
\hline & Okur-yazar & 13 & 30,77 & 5,97 & & & \\
\hline & İlkokul & 37 & 26,84 & 5,26 & & & \\
\hline & Ortaokul & 13 & 26,85 & 3,93 & & & \\
\hline & Lise & 37 & 29,81 & 4,83 & & & \\
\hline & Yüksekokul/Üniversite & 85 & 31,67 & 4,51 & & & \\
\hline & $\begin{array}{ll}\text { Lisansüstü } & \text { (YL- } \\
\text { Doktora) } & \\
\end{array}$ & 14 & 30,50 & 4,03 & & & \\
\hline \multirow{7}{*}{$\begin{array}{l}\text { Geleneksel } \\
\text { Cinsiyet } \\
\text { Rolü }\end{array}$} & Okur-yazar değil & 2 & 12,00 & 2,83 & \multirow{7}{*}{5,597} & \multirow{7}{*}{, $000^{*}$} & \multirow{7}{*}{$\begin{array}{l}\text { İlkokul- } \\
\text { Lise } \\
\text { İlkokul- } \\
\text { Yüksekokul }\end{array}$} \\
\hline & Okur-yazar & 13 & 18,54 & 6,29 & & & \\
\hline & İlkokul & 37 & 16,41 & 5,09 & & & \\
\hline & Ortaokul & 13 & 16,62 & 6,34 & & & \\
\hline & Lise & 37 & 20,43 & 5,72 & & & \\
\hline & Yüksekokul/Üniversite & 85 & 21,91 & 5,21 & & & \\
\hline & $\begin{array}{l}\text { Lisansüstü } \quad \text { (YL- } \\
\text { Doktora) }\end{array}$ & 14 & 18,93 & 6,75 & & & \\
\hline \multirow{6}{*}{$\begin{array}{l}\text { Erkek } \\
\text { Cinsiyet } \\
\text { Rolü }\end{array}$} & Okur-yazar değil & 2 & 17,50 & 71 & \multirow{6}{*}{3,668} & \multirow{6}{*}{, $002^{*}$} & \multirow{6}{*}{$\begin{array}{l}\text { İlkokul- } \\
\text { Yüksekokul }\end{array}$} \\
\hline & Okur-yazar & 13 & 21,69 & 5,44 & & & \\
\hline & İlkokul & 37 & 18,81 & 4,43 & & & \\
\hline & Ortaokul & 13 & 19,69 & 4,17 & & & \\
\hline & Lise & 37 & 20,73 & 3,74 & & & \\
\hline & Yüksekokul/Üniversite & 85 & 22,38 & 4,26 & & & \\
\hline
\end{tabular}




\begin{tabular}{|c|c|c|c|c|c|c|c|}
\hline & $\begin{array}{l}\text { Lisansüstü } \quad \text { (YL- } \\
\text { Doktora) }\end{array}$ & 14 & 20,36 & 4,14 & & & \\
\hline \multirow{7}{*}{$\begin{array}{l}\text { Toplam } \\
\text { Cinsiyet } \\
\text { Rolü }\end{array}$} & Okur-yazar değil & 2 & 102,00 & 19,80 & \multirow{7}{*}{8,469} & \multirow{7}{*}{, $000^{*}$} & \multirow{7}{*}{$\begin{array}{l}\text { İlkokul- } \\
\text { Lise } \\
\text { İlkokul- } \\
\text { Yüksekokul }\end{array}$} \\
\hline & Okur-yazar & 13 & 117,46 & 27,62 & & & \\
\hline & İlkokul & 37 & 108,35 & 16,02 & & & \\
\hline & Ortaokul & 13 & 110,08 & 15,99 & & & \\
\hline & Lise & 37 & 120,89 & 17,76 & & & \\
\hline & Yüksekokul/Üniversite & 85 & 130,93 & 17,27 & & & \\
\hline & $\begin{array}{l}\text { Lisansüstï } \quad \text { (YL- } \\
\text { Doktora) }\end{array}$ & 14 & 121,00 & 20,03 & & & \\
\hline
\end{tabular}

$\left.{ }^{*}\right)$ işareti farkın anlamlı olduğunu göstermektedir; $\mathrm{p}<0.05$

Tablo 3 incelendiğinde, erkeklerin toplumsal cinsiyet rollerine ilişkin tutumları ile eğitim düzeyleri arasındaki farklılıklar gözlenmektedir. Eşitlikçi cinsiyet rolü alt boyutunda, okur-yazar olmayanların aritmetik ortalamaları 30.50, okur-yazar olanların aritmetik ortalamaları 30.31, ilkokul mezunu olanları aritmetik ortalamaları 30.09, ortaokul mezunu olanların aritmetik ortalamaları 31.08, lise mezunu olanların aritmetik ortalamaları 31.00, yüksekokul/üniversite mezunu olanların aritmetik ortalamaları 33.14, lisansüstü(YLDoktora) mezunu olanların aritmetik ortalamaları ise, 32.29'dur. Kadın cinsiyet rolü alt boyutunda, okur-yazar olmayanların aritmetik ortalamaları 14.50, okur-yazar olanların aritmetik ortalamaları 16.15, ilkokul mezunu olanları aritmetik ortalamaları 16.22, ortaokul mezunu olanların aritmetik ortalamaları 15.85, lise mezunu olanların aritmetik ortalamaları 18.92, yüksekokul/üniversite mezunu olanların aritmetik ortalamaları 21.84, lisansüstü (YLDoktora) mezunu olanların aritmetik ortalamaları ise, 18.93'dür. Evlilikte cinsiyet rolü alt boyutunda okur-yazar olmayanların aritmetik ortalamaları 27.50, okur-yazar olanların aritmetik ortalamaları 30.77, ilkokul mezunu olanları aritmetik ortalamaları 26.84, ortaokul mezunu olanların aritmetik ortalamaları 26.85, lise mezunu olanların aritmetik ortalamaları 29.81, yüksekokul/üniversite mezunu olanların aritmetik ortalamaları 31.67, lisansüstü (YLDoktora) mezunu olanların aritmetik ortalamaları ise, 30.50'dir. Geleneksel cinsiyet rolü alt boyutuna göre; okur-yazar olmayanların aritmetik ortalamaları 12.00, okur-yazar olanların aritmetik ortalamaları 18.54, ilkokul mezunu olanları aritmetik ortalamaları 16.41, ortaokul mezunu olanların aritmetik ortalamaları 16.62, lise mezunu olanların aritmetik ortalamaları 20.43, yüksekokul/üniversite mezunu olanların aritmetik ortalamaları 21.91, lisansüstü (YLDoktora) mezunu olanların aritmetik ortalamaları ise, 18.93'dür. Erkek cinsiyet rolü alt boyutunda, okur-yazar olmayanların aritmetik ortalamaları 17.50, okur-yazar olanların aritmetik ortalamaları 21.69, ilkokul mezunu olanların aritmetik ortalamaları 18.81, ortaokul mezunu olanların aritmetik ortalamaları 19.69, lise mezunu olanların aritmetik ortalamaları 20.73, yüksekokul/üniversite mezunu olanların aritmetik ortalamaları 22.38, lisansüstü (YLDoktora) mezunu olanların aritmetik ortalamaları ise, 20.36'dır. Toplumsal cinsiyet rolü toplam puana göre okur-yazar olmayanların aritmetik ortalamaları 102.00, okur-yazar olanların aritmetik ortalamaları 117.46, ilkokul mezunu olanları aritmetik ortalamaları 108.35, ortaokul mezunu olanların aritmetik ortalamaları 110.08, lise mezunu olanların aritmetik ortalamaları 120.89, yüksekokul/üniversite mezunu olanların aritmetik ortalamaları 130.93, lisansüstü (YL-Doktora) mezunu olanların aritmetik ortalamaları ise, 121.00 'dir. Eşitlikçi cinsiyet rolü alt boyutunda hesaplanan F değeri “2.178” ( $\mathrm{p}<0.05)$, kadın cinsiyet rolü alt boyutunda hesaplanan F değeri "6.231" ( $p<0.05)$, evlilikte cinsiyet rolü alt 
boyutunda hesaplanan F değeri "5.597" $(\mathrm{p}<0.05)$, geleneksel cinsiyet rolü alt boyutunda hesaplanan F değeri "5.597" ( $\mathrm{p}<0.05)$, erkek cinsiyet rolü alt boyutunda hesaplanan F değeri "3.668" ( $\mathrm{p}<0.05)$, toplumsal cinsiyet rolü toplam puanda hesaplanan F değeri ise, "8.469" $(\mathrm{p}<0.05)^{\prime}$ dir. Sonuçlara göre toplumsal cinsiyet rolleri tutumu eğitim düzeyine göre tüm alt boyutlarda anlamlı bulunmuştur.

Tablo 4. Toplumsal Cinsiyet Rolleri Alt Boyutlarının Evlilik Şekline Göre ANOVA Sonuçları

\begin{tabular}{|c|c|c|c|c|c|c|c|}
\hline Boyutlar & Evlenme Şekli & $\mathbf{N}$ & $x$ & ss & $\mathbf{F}$ & $\mathrm{p}$ & $\begin{array}{l}\text { Anlam } \\
\text { (Scheffe } \\
\text { Testi) }\end{array}$ \\
\hline \multirow{3}{*}{$\begin{array}{l}\text { Eşitlikçi } \\
\text { Cinsiyet } \\
\text { Rolüi }\end{array}$} & $\begin{array}{l}\text { Severek/Flört } \\
\text { Ederek }\end{array}$ & 45 & 32,67 & 4,37 & \multirow{3}{*}{8,751} & \multirow{3}{*}{, $000^{*}$} & \multirow{3}{*}{$\begin{array}{l}\text { Severek/Flört } \\
\text { Ederek- } \\
\text { Görücü } \\
\text { Usulü/ } \\
\text { İsteyerek }\end{array}$} \\
\hline & $\begin{array}{ll}\text { Görücü } & \text { Usulü/ } \\
\text { İsteyerek } & \\
\end{array}$ & 82 & 30,04 & 5,35 & & & \\
\hline & $\begin{array}{l}\text { Görücü } \\
\text { Usulü/İstemeyerek }\end{array}$ & 74 & 33,16 & 4,71 & & & \\
\hline \multirow{3}{*}{$\begin{array}{l}\text { Kadın } \\
\text { Cinsiyet } \\
\text { Rolüi }\end{array}$} & $\begin{array}{l}\text { Severek/Flört } \\
\text { Ederek }\end{array}$ & 45 & 20,67 & 5,42 & \multirow{3}{*}{12,631} & \multirow{3}{*}{, $000^{*}$} & \multirow{3}{*}{$\begin{array}{l}\text { Severek/Flört } \\
\text { Ederek- } \\
\text { Görücü } \\
\text { Usulü/ } \\
\text { İsteyerek }\end{array}$} \\
\hline & $\begin{array}{ll}\text { Görücü } & \text { Usulü/ } \\
\text { İsteyerek }\end{array}$ & 82 & 16,74 & 5,81 & & & \\
\hline & $\begin{array}{l}\text { Görücü } \\
\text { Usulü/İstemeyerek }\end{array}$ & 74 & 21,12 & 6,14 & & & \\
\hline \multirow{3}{*}{$\begin{array}{l}\text { Evlilikte } \\
\text { Cinsiyet } \\
\text { Rolü }\end{array}$} & $\begin{array}{l}\text { Severek/Flört } \\
\text { Ederek }\end{array}$ & 45 & 30,76 & 4,26 & \multirow{3}{*}{3,826} & \multirow{3}{*}{, $023^{*}$} & \multirow{3}{*}{$\begin{array}{l}\text { Severek/Flört } \\
\text { Ederek- } \\
\text { Görücü } \\
\text { Usulü/ } \\
\text { İsteyerek }\end{array}$} \\
\hline & $\begin{array}{ll}\text { Görücü } & \text { Usulü/ } \\
\text { İsteyerek } & \end{array}$ & 82 & 28,77 & 5,07 & & & \\
\hline & $\begin{array}{l}\text { Görücü } \\
\text { Usulü/İstemeyerek }\end{array}$ & 74 & 30,76 & 5,34 & & & \\
\hline \multirow{3}{*}{$\begin{array}{l}\text { Geleneksel } \\
\text { Cinsiyet } \\
\text { Rolü }\end{array}$} & $\begin{array}{l}\text { Severek/Flört } \\
\text { Ederek }\end{array}$ & 45 & 20,38 & 6,12 & \multirow{3}{*}{1,888} & \multirow{3}{*}{ 154 } & \multirow{3}{*}{ - } \\
\hline & $\begin{array}{ll}\text { Görücü } & \text { Usulü/ } \\
\text { İsteyerek } & \end{array}$ & 82 & 18,78 & 5,92 & & & \\
\hline & $\begin{array}{l}\text { Görücü } \\
\text { Usulü/İstemeyerek }\end{array}$ & 74 & 20,46 & 5,77 & & & \\
\hline \multirow{3}{*}{$\begin{array}{l}\text { Erkek } \\
\text { Cinsiyet } \\
\text { Rolü }\end{array}$} & $\begin{array}{l}\text { Severek/Flört } \\
\text { Ederek }\end{array}$ & 45 & 21,91 & 4,38 & \multirow{3}{*}{2,047} & \multirow{3}{*}{ 132 } & \multirow{3}{*}{ - } \\
\hline & $\begin{array}{ll}\text { Görücü } & \text { Usulü/ } \\
\text { İsteyerek } & \\
\end{array}$ & 82 & 20,32 & 4,37 & & & \\
\hline & $\begin{array}{l}\text { Görücü } \\
\text { Usulü/İstemeyerek }\end{array}$ & 74 & 21,23 & 4,46 & & & \\
\hline \multirow{3}{*}{$\begin{array}{l}\text { Toplam } \\
\text { Cinsiyet } \\
\text { Rolü }\end{array}$} & $\begin{array}{l}\text { Severek/Flört } \\
\text { Ederek }\end{array}$ & 45 & 126,38 & 17,57 & \multirow{3}{*}{9,362} & \multirow{3}{*}{, $000^{*}$} & \multirow{3}{*}{$\begin{array}{l}\text { Severek/Flört } \\
\text { Ederek- } \\
\text { Görücü } \\
\text { Usulü/ } \\
\text { İsteyerek }\end{array}$} \\
\hline & $\begin{array}{l}\text { Görücü } \quad \text { Usulü/ } \\
\text { İsteyerek }\end{array}$ & 82 & 114,66 & 19,87 & & & \\
\hline & $\begin{array}{l}\text { Görücü } \\
\text { Usulü/İstemeyerek }\end{array}$ & 74 & 126,73 & 19,45 & & & \\
\hline
\end{tabular}


$\left(^{*}\right)$ işareti farkın anlamlı olduğunu göstermektedir; $\mathrm{p}<0.05$

(-) işareti farkın anlamlı olmadığını göstermektedir; $p>0.05$

Tablo 4 incelendiğinde, erkeklerin toplumsal cinsiyet rollerine ilişkin tutumları ile evlilik şekilleri arasındaki farklılıklar gözlenmektedir. Eşitlikçi cinsiyet rolüne alt boyutuna göre; severek/flört ederek evlenenlerin aritmetik ortalamaları 32.67, görücü usulü/isteyerek evlenenlerin aritmetik ortalamaları 30.04, görücü usulü/istemeyerek evlenenlerin aritmetik ortalamaları ise 33.16 'dır. Kadın cinsiyet rolü alt boyutuna göre; severek/flört ederek evlenenlerin aritmetik ortalamaları 20.67, görücü usulü/isteyerek evlenenlerin aritmetik ortalamaları 16.74, görücü usulü/istemeyerek evlenenlerin aritmetik ortalamaları ise, 21.12'dir. Evlilikte cinsiyet rolleri alt boyutuna göre; severek/flört ederek evlenenlerin aritmetik ortalamaları 30.76, görücü usulü/isteyerek evlenenlerin aritmetik ortalamaları 28.77, görücü usulü/istemeyerek evlenenlerin aritmetik ortalamaları ise, 30.76 'dır. Geleneksel cinsiyet rolü alt boyutuna göre; severek/flört ederek evlenenlerin aritmetik ortalamaları 20.38, görücü usulü/isteyerek evlenenlerin aritmetik ortalamaları 18.78, görücü usulü/istemeyerek evlenenlerin aritmetik ortalamaları ise, $20.46^{\prime}$ dır. Erkek cinsiyet rolü alt boyutuna göre; severek/flört ederek evlenenlerin aritmetik ortalamaları 21.91, görücü usulü/isteyerek evlenenlerin aritmetik ortalamaları 20.32, görücü usulü/istemeyerek evlenenlerin aritmetik ortalamaları ise, 21.23 'dür. Toplumsal cinsiyet rolü toplam puana göre; severek/flört ederek evlenenlerin aritmetik ortalamaları 126.38, görücü usulü/isteyerek evlenenlerin aritmetik ortalamaları 114.66, görücü usulü/istemeyerek evlenenlerin aritmetik ortalamaları ise, 126.73 'dür. Eşitlikçi cinsiyet rolü alt boyutunda hesaplanan F değeri "8.751" $(\mathrm{p}<0.05)$, kadın cinsiyet rolü alt boyutunda hesaplanan F değeri "12.631" ( $>>0.05)$, evlilikte cinsiyet rolü alt boyutunda hesaplanan F değeri "3.826" ( $p<0.05)$, geleneksel cinsiyet rolü alt boyutunda hesaplanan $\mathrm{F}$ değeri "1.888" ( $>>0.05)$, erkek cinsiyet rolü alt boyutunda hesaplanan F değeri "2.047" ( $>0.05)$, toplumsal cinsiyet rolü toplam puanda hesaplanan F değeri ise "9.362" ( $\mathrm{p}<0.05)^{\prime}$ dir. Sonuçlara göre toplumsal cinsiyet rolleri tutumu evlenme şekline göre, geleneksel cinsiyet rolü $(\mathrm{F}=1.888, \mathrm{p}>0.05)$ ve erkek cinsiyet rolü $(\mathrm{F}=2.047, \mathrm{p}>0.05)$ hariç tüm alt boyutlarda anlamlı bulunmuştur.

Tablo 5. Toplumsal Cinsiyet Rolleri Alt Boyutlarının Din Referansına Göre ANOVA Sonuçları

\begin{tabular}{|c|c|c|c|c|c|c|c|}
\hline Boyutlar & $\begin{array}{l}\text { Dinin Duygu ve } \\
\text { Düşünceleri } \\
\text { Etkilemesi(İslam) }\end{array}$ & $\mathbf{N}$ & $x$ & Ss & $\mathbf{F}$ & $\mathbf{P}$ & $\begin{array}{l}\text { Anlam } \\
\text { (Scheffe } \\
\text { Testi) }\end{array}$ \\
\hline \multirow{4}{*}{$\begin{array}{l}\text { Eşitlikçi } \\
\text { Cinsiyet } \\
\text { Rolüi }\end{array}$} & Büyük oranda & 128 & 31,26 & 5,08 & \multirow{4}{*}{1,712} & \multirow{4}{*}{ 166 } & \multirow{4}{*}{-} \\
\hline & Az etkiler & 61 & 32,82 & 4,97 & & & \\
\hline & Hiç etkilemez & 9 & 33,00 & 4,97 & & & \\
\hline & İnanmiyorum & 3 & 29,33 & 7,51 & & & \\
\hline \multirow{4}{*}{$\begin{array}{l}\text { Kadın } \\
\text { Cinsiyet } \\
\text { Rolü }\end{array}$} & Büyük oranda & 128 & 17,58 & 5,58768 & \multirow{4}{*}{10,241} & \multirow{4}{*}{, $000^{*}$} & \multirow{4}{*}{$\begin{array}{l}\text { Büyük } \\
\text { oranda- } \\
\text { Az etkiler }\end{array}$} \\
\hline & Az etkiler & 61 & 22,10 & 5,77 & & & \\
\hline & Hiç etkilemez & 9 & 21,00 & 7,43 & & & \\
\hline & İnanmiyorum & 3 & 26,33 & 10,12 & & & \\
\hline \multirow{2}{*}{$\begin{array}{l}\text { Evlilikte } \\
\text { Cinsiyet }\end{array}$} & Büyük oranda & 128 & 29,42 & 4,92 & \multirow{2}{*}{2,159} & \multirow{2}{*}{,094 } & \multirow{2}{*}{ - } \\
\hline & Az etkiler & 61 & 31,18 & 5,24 & & & \\
\hline
\end{tabular}




\begin{tabular}{|c|c|c|c|c|c|c|c|}
\hline \multirow[t]{2}{*}{ Rolü } & Hiç etkilemez & 9 & 28,33 & 5,15 & & & \\
\hline & İnanmiyorum & 3 & 32,00 & 5,29 & & & \\
\hline \multirow{4}{*}{$\begin{array}{l}\text { Geleneksel } \\
\text { Cinsiyet } \\
\text { Rolü }\end{array}$} & Büyük oranda & 128 & 18,34 & 5,21548 & \multirow{4}{*}{8,473} & \multirow{4}{*}{, $000^{*}$} & \multirow{4}{*}{$\begin{array}{l}\text { Büyük } \\
\text { oranda- } \\
\text { Az etkiler }\end{array}$} \\
\hline & Az etkiler & 61 & 22,70 & 6,05 & & & \\
\hline & Hiç etkilemez & 9 & 19,22 & 7,68 & & & \\
\hline & İnanmıyorum & 3 & 22,00 & 7,94 & & & \\
\hline \multirow{4}{*}{$\begin{array}{l}\text { Erkek } \\
\text { Cinsiyet } \\
\text { Rolü }\end{array}$} & Büyük oranda & 128 & 20,36 & 4,57 & \multirow{4}{*}{3,596} & \multirow{4}{*}{, $015^{*}$} & \multirow{4}{*}{$\begin{array}{l}\text { Büyük } \\
\text { oranda- } \\
\text { Az etkiler }\end{array}$} \\
\hline & Az etkiler & 61 & 22,51 & 3,90 & & & \\
\hline & Hiç etkilemez & 9 & 19,89 & 3,66 & & & \\
\hline & İnanmiyorum & 3 & 21,67 & 4,73 & & & \\
\hline \multirow{4}{*}{$\begin{array}{l}\text { Toplam } \\
\text { Cinsiyet } \\
\text { Rolü }\end{array}$} & Büyük oranda & 128 & 116,95 & 18,58 & \multirow{4}{*}{8,101} & \multirow{4}{*}{, $000^{*}$} & \multirow{4}{*}{$\begin{array}{l}\text { Büyük } \\
\text { oranda- } \\
\text { Az etkiler }\end{array}$} \\
\hline & Az etkiler & 61 & 131,31 & 18,72 & & & \\
\hline & Hiç etkilemez & 9 & 121,44 & 23,10 & & & \\
\hline & İnanmiyorum & 3 & 131,33 & 32,93 & & & \\
\hline
\end{tabular}

(*) işareti farkın anlamlı olduğunu göstermektedir; $p<0.05$

(-) işareti farkın anlamlı olmadığını göstermektedir; $p>0.05$

Tablo 5 incelendiğinde, erkeklerin toplumsal cinsiyet rollerine ilişkin tutumları ile dinin (İslam) duygu ve düşüncelerini etkilemesi arasındaki farklılıklar gözlenmektedir. Eşitlikçi cinsiyet rolü alt boyutunda "dinin (İslam) duygu ve düşüncelerini büyük ölçüde etkilediğini" ifade eden katılımcıların aritmetik ortalamaları 31.26, "dinin duygu ve düşüncelerini az etkilediği"ni ifade eden katılımcıların aritmetik ortalamaları 32.82, "dinin duygu ve düşüncelerini hiç etkilemediğini" belirten katılımcıların aritmetik ortalamaları 33.00, "dine inanmıyorum" şeklinde yanıt veren katılımcıların aritmetik ortalamaları ise 29.33'dür. Kadın cinsiyet rolü alt boyutunda "dinin (İslam) duygu ve düşüncelerini büyük ölçüde etkilediğini" söyleyen erkeklerin aritmetik ortalamaları 17.58, "az etkiler" yanıtını verenlerin aritmetik ortalamaları 22.10, "hiç etkilemez" yanıtını verenlerin aritmetik ortalamaları 21.00, "dine inanmıorum" yanıtını verenlerin aritmetik ortalamaları 26.33'dür. Evlilikte cinsiyet rolü alt boyutunda "dinin (İslam) duygu ve düşüncelerini büyük ölçüde etkilediğini" ifade eden erkeklerin aritmetik ortalamaları 29.42, "az etkiler" yanitı verenlerin aritmetik ortalamaları 31.18, "hiç etkilemez" yanıtını verenlerin aritmetik ortalamaları 28.33, "dine inanmıyorum" yanıtını verenlerin aritmetik ortalamaları 32.00'dır. Geleneksel cinsiyet rolü alt boyutunda "dinin (İslam) duygu ve düşüncelerini büyük ölçüde etkilediğini" ifade eden erkeklerin aritmetik ortalamaları 18.34, "az etkiler" yanıtını verenlerin aritmetik ortalamaları 22.70, "hiç etkilemez" yanıtını verenlerin aritmetik ortalamaları 19.22, "dine inanmıyorum" yanıtını verenlerin aritmetik ortalamaları ise 22.00'dir. Erkek cinsiyet rolü alt boyutunda "dinin (İslam) duygu ve düşüncelerini büyük ölçüde etkilediğini" ifade eden erkeklerin aritmetik ortalamaları 20.36, "az etkiler" yanıtını verenlerin aritmetik ortalamaları 22.51, "hiç etkilemez" yanıtını verenlerin aritmetik ortalamaları 19.89, "dine inanmıorum" yanıtını verenlerin aritmetik ortalamaları 21.67 'dir. Toplumsal cinsiyet rolü tutumu toplam puan açısından bakıldığında, "dinin (İslam) duygu ve düşüncelerini büyük ölçüde etkilediğini" ifade eden erkeklerin aritmetik ortalamaları 116.95, "az etkiler" yanıtını verenlerin aritmetik ortalamaları 131.31, "hiç etkilemez" yanıtını verenlerin aritmetik ortalamaları 121.44, "dine inanmıyorum" yanıtını verenlerin aritmetik ortalamaları ise, 131.33 'dür. Eşitlikçi cinsiyet rolü alt boyutunda hesaplanan F değeri “1.712” (p>0.05), kadın 
cinsiyet rolü alt boyutunda hesaplanan F değeri "10.241" ( $\mathrm{p}<0.05$ ), evlilikte cinsiyet rolü alt boyutunda hesaplanan F değeri "2.159" ( $\mathrm{p}>0.05)$, geleneksel cinsiyet rolü alt boyutunda hesaplanan F değeri "8.473" ( $\mathrm{p}<0.05)$, erkek cinsiyet rolü alt boyutunda hesaplanan F değeri "3.596" ( $\mathrm{p}<0.05)$, toplumsal cinsiyet rolü toplam puanda hesaplanan F değeri ise "8.101" $(\mathrm{p}<0.05)^{\prime}$ dir. Sonuçlara göre değerlendirildiğinde toplumsal cinsiyet rolleri tutumu, dinin duyguları ve düşünceleri etkileme oranına göre eşitlikçi cinsiyet rolü $(\mathrm{F}=1.712, \mathrm{p}>0.05)$ ve evlilikte cinsiyet rolü $(\mathrm{F}=2.159, \mathrm{p}>0.05)$ hariç tüm alt boyutlarda anlamlı bulunmuştur.

\section{TARTIŞMA VE SONUÇ}

1. Erkeklerin toplumsal cinsiyet rollerine ilişkin tutumları ile yaşları arasındaki farklılıklara bakıldığında, elde edilen sonuçlara göre toplumsal cinsiyet rolleri tutumu erkek cinsiyet rolü hariç ( $\mathrm{F}=1.783, \mathrm{p}>0.05)$ tüm alt boyutlarda anlamlı bulunmuştur. Anlamlı olan alt boyutlara bakıldığında, yaşlar büyüdükçe puan ortalamaları küçülmüştür. Ölçekten alınan toplam puanlar değerlendirildiğinde yüksek puan eşitlikçi, düşük puan geleneksel rolü vurgulamaktadır. Gençlerin cinsiyet rol tavrının incelenmesi, çeşitli nedenlerle, özellikle şu anki görüşlerin sonraki davranış hakkında önceden ipucu vermesi açısından önemlidir (Mensch-Ibrahim vd. 2003). Orta yaşlı erkeklerin çaba ve hırsla daha az ilgili olduğu ve bunun yerine sürecin keyfi, deneyimin niteliği, duygusal bağlllık gibi daha içsel motivasyonlarla ilgilendikleri öne sürülmektedir (Cournoyer-Mahalik 1995). Erkeklerin cinsiyet rolünün değişen özelliklerine ilişkin teori ve araştırmalar, erkeklerin yaşlarına göre kişiliklerinin kadınsı yönlerini ifade etme ve daha nazik olma yönünde değiştiklerini öne sürmektedir (Cournoyer- Mahalik 1995). Bu bulgular ışığında, elde edilen bulgulardan yola çıkarak erkelerin yaşları arttıkça daha geleneksel tutuma sahip oldukları söylenebilir.

2. Erkeklerin toplumsal cinsiyet rollerine ilişkin tutumları ile eğitim düzeyleri arasındaki farklılıklar ele alındığında, elde edilen sonuçlara göre toplumsal cinsiyet rolleri tutumunun eğitim düzeyine göre tüm alt boyutlarda anlamlı olduğu görülmektedir. Ölçekten alınan toplam puanlar değerlendirildiğinde, yüksek puan eşitlikçi, düşük puan geleneksel rolü vurgulamaktadır. Eğitim seviyesine göre en yüksek puan yüksekokul/üniversite mezunlarına aittir. En düşük puan ise okur-yazar olmayanlarındır. Ersoy (2009) yaptığı çalışmada eğitim seviyesi yükseldikçe erkeklerin geleneklere bağlılıkları açısından bir değişim yaşandığı sonucuna ulaşmıştır. Eğitim düzeyi yüksek olan bireylerin büyük oranda büyük ya da orta ölçekli şehirlerde öğrenim gördükleri düşünüldüğünde, bu bireylerin daha çok şehir kültürüne aşina oldukları ve sosyal etkileşimlerde bulundukları, ayrıca farklı düşüncelere ve bakış açlarına sahip insanlarla bir şekilde iletişime girdikleri, bundan dolayı da toplumsal cinsiyet bakış açılarının çok katı olmadığı söylenebilir (AkgülGök 2013). Buradan yola çıkarak yüksekokul mezunlarının daha eşitlikçi, okuryazar olmayanların ise daha geleneksel tutuma sahip oldukları söylenebilir.

3. Erkeklerin toplumsal cinsiyet rollerine ilişkin tutumları ile evlenme şekli arasındaki farklılıklar değerlendirildiğinde, elde edilen sonuçlar toplumsal cinsiyet rolleri tutumu evlenme şekline göre, geleneksel cinsiyet rolü $(\mathrm{F}=1.888, \mathrm{p}>0.05)$ ve erkek cinsiyet rolü $(\mathrm{F}=2.047, \mathrm{p}>0.05)$ hariç, tüm alt boyutlarda anlamlı bulunmuştur. Anlamlı olan alt boyutlara bakıldığında, tüm anlamlı alt boyutlarda severek/flört ederek evlenenler ile görücü usulü/isteyerek evlenenler arasında anlamlı bir farklılık olduğu görülmektedir. Daha az geleneksel cinsiyet rolüne sahip erkekler hem geleneksel hem de geleneksel olmayan rol birleşenlerine sahiptirler. Ayrıca daha az tutarlıdırlar ve anlık değişimlerden etkilenebilirler. Geleneksel erkek rolüne sahip olan erkekler ise daha dar ve keskin bir şekilde tanımlanmış 
erkek rolü imgelerine sahiptirler. Geleneksel erkek tutumu daha tutarlıdır ve anlık değişimlerden etkilenmez. (Garst-Bodenhausen 1997). Buna paralel olarak geleneksel evliliklerde erkekler çoğunlukla geleneksel erkek cinsiyet rolünü benimsemişlerdir. Geleneksel olmayan evliliklerde ise, yeni roller denenebileceği için ortaya çıkması muhtemel anlaşmazlıkların uygun biçimde çözülmesi evlilik doyumunu arttırabilir (Şendil-Korkut 2008). Bunu destekler nitelikte görücü usulü zorla evlenenlerin evlilik uyum düzeyleri, görücü usulü isteyerek ve flört ederek evlenenlere göre daha düşük bulunmuştur (Gül 2016).

4. Erkeklerin toplumsal cinsiyet rollerine ilişkin tutumları ile dini referans alma arasındaki farklılıklara bakıldığında, elde edilen sonuçlara göre, toplumsal cinsiyet rolleri tutumu dinin duyguları ve düşünceleri etkileme oranına göre eşitlikçi cinsiyet rolü ( $\mathrm{F}=1.712$, $\mathrm{p}>0.05)$ ve evlilikte cinsiyet rolü $(\mathrm{F}=2.159, \mathrm{p}>0.05)$ hariç, tüm alt boyutlarda anlamlı bulunmuştur. Anlamlı olan alt boyutlar incelendiğinde, "din duygu ve düşüncelerimi büyük oranda etkiler" yanıtını veren erkekler ile "din duygu ve düşüncelerimi az etkiler" yanıtını veren erkekler arasında anlamlı bir farkın olduğu görülmektedir. Buna göre, dinin duygu ve düşünceleri etkilemesi anlamında, erkeklerin toplumsal cinsiyet rolü tutumlarını anlamlı düzeyde farklılaştırdığı görülmektedir. Bu farklılaşma eşitlikçi cinsiyet rolünde ve evlilikte cinsiyet rolünde anlamsızdır. Evlilikte eşler daha geleneksel hale geldikçe, bir diğeri tarafından kötü muamele gördükleri veya sömürüldüklerini hissedebilirler ve bu nedenle evliliklerinden daha az mutlu olabilirler. Eşler arasında değişen rollere, erkek daha dirençli olabilir (Amato-Booth 1995). Hünler (2002)'in yaptığı çalışmada dindarlık evlilik doyumunu yordamaktadır. Aynı çalışmada evlilik sorunlarını çözme ile boyun eğici davranışlar arasındaki ilişkiye vurgu yapılmıştır. Geleneksel erkek cinsiyet rolünde çoğunlukla kadından boyun eğici olması beklenir ve bu şekilde problemlerin üstesinden gelinmeye çalışılır. Geleneksel toplumsal cinsiyet rolü toplumda kadınların ve erkeklerin nasıl davranmaları gerektiği konusundaki algıları yansıtır. Geleneksel cinsiyet rolüne sahip bir erkeğin ilişkilerinde daha baskıcı olması muhtemeldir (Andersen-Cyranowski-Espindle 1999). Bu noktadan hareketle, erkeklerde toplumsal cinsiyet rolü tutumları açısından dinin, duygu ve düşünceleri etkilemesinin evlilikte ve geleneksel cinsiyet rolünde bir farklılaşma oluşturmaması, dini referanslardan değil kültürel bakış açısından ya da kişisel tercihlerden kaynaklanıyor olabilir.

\section{SUMMARY}

Gender is the basic equal distinction that separates men and women from each other. Biological sex, which expresses this discrimination, is usually defined using biological markers. Gender is defined using social practices, stereotypes and roles of gender. Of course, differences in everyday life are often shaped by gender roles. Socializers, such as the family, education, culture, religion and the media, define gender roles. Thus, definitions of masculinity and femininity are transformed into learned forms of expressing masculinity and femininity in order to encode and regulate cultural knowledge.

One of the most significant changes in family life over the last two decades is the change of male and female roles. Contrary to traditional marriages where the husband is only a worker, where women take care of your home and child care, modern marriages are widespread, where women take on the role of wife, mother and worker at the same time. Therefore, gender roles, which affect almost every aspect of people's daily lives, are an important issue that must be studied in the context of modern marriages.

SEFAD, 2018 (39): 355-372 
The gender studies show that traditional views of men about gender roles affect the status of women in society. Nevertheless, when we look at studies on gender roles and attitudes in the literature, it is seen that there is less research on men than women. This study, which also aims to contribute to the literature in this direction, aims to evaluate the attitudes of men towards gender roles from different perspectives.

The purpose of this study is to assess the attitudes of men towards gender roles from different perspectives. The study group of the study is composed of 201 men selected by simple random sampling residing in Konya province. The distribution of males according to their ages is like; 54 individuals $(26.9 \%)$ are in the age range of $18-25$ years, 59 individuals $(29.4 \%)$ are in the age range of $26-40$ years, 47 individuals $(23.4 \%)$ are in the age range of 41 55 years, and 41 individuals $(20.4 \%)$ are 56 years and over. As a method of collecting data in the survey, a personal information form and a questionnaire form including the gender role attitude scale were used. The personal information form was prepared by the researchers and the gender role attitude scale was developed by Zeyneloğlu-Terzioğlu in 2011 and is a scale that consists of a total of 38 items. Frequency analysis and ANOVA methods were used to analyze the data obtained from the study. Findings indicate that differences between gender attitudes of males and their ages are significant in all subscales except for male gender role. Considering the differences between the attitudes towards gender roles and the levels of education, gender role attitude was found to be significant in all sub-dimensions compared to education level. When the differences between gender role attitudes and marriage patterns are examined, according to the obtained results, gender role attitude to marriage patterns was found to be significant in all sub-dimensions except for traditional gender role and male gender role. Gender role attitude was found to be significant in all subdimensions except for the egalitarian gender role and the sex role in marriage, according to the rate of religion affecting feelings and thoughts. The obtained results were discussed in the light of relevant literature. 


\section{KAYNAKÇA}

Addis, Michael E.\& Mahalik, James R. (2003). "Men, Masculinity, And the Contexts of Help Seeking". American Psychologist 58(1): 5-14.

Agacinski, Sylviane (1998). Cinsiyetler Siyaseti. Çev. İ. Yerguz. Ankara: Dost Kitabevi

Akgül-Gök, Fulya (2013). Evli Kadın ve Erkeklerin Toplumsal Cinsiyet Rolleriyle Ilgili Algilarmnn Aile İşlevlerine Yansıması. Yüksek Lisans Tezi. Ankara: Hacettepe Ü.

Amato, Paul R. \& Booth, Alan (1995). "Changes in Gender Role Attitudes and Perceived Marital Quality". American Sociological Review 60 (1): 58-66.

Andersen, Barbara L. \& Cyranowski, Jill M. vd (1999). "Men's Sexual Self-schema”. J Pers Soc Psychol, (76): 645-661.

Öngen, Burcu-Aytaç, Serpil (2013). “Üniversite Öğrencilerinin Toplumsal Cinsiyet Rollerine İlişkin Tutumları ve Yaşam Değerleri İlişkisi". Sosyoloji Konferansları, 48 (2013-2): 1-18.

Basow, Susan A. (1992). Gender: Stereotypes And Roles. Belmont, CA, US: Thomson Brooks/Cole Publishing Co.

Bem, Sandra Lipsitz (1981). "Gender Schema Theory: A Cognitive Account of Sex Typing". Psychological Review, 88 (4): 354-364.

Blee, Kathleen M. \& Tickamyer, Ann R. (1995). “Racial Differences in Men's Attitudes about Women's Gender Roles". Journal of Marriage and Family, 57, (1): 21-30

Bussey, Kay \& Bandura, Albert (1999). "Social Cognitive Theory of Gender Development And Differentiation". Psychological Review, (106): 676-713.

Can, İslam (2013). "Tarih, Toplum ve Kültür Bağlamında Aile ve Kadın”. Sistematik Aile Sosyolojisi. Ed. M. Aydın. Konya: Çizgi Kitabevi. 3. Baskı.

Cassidy, Margaret L. \& Warren, Bruce O. (1996). "Family Employment Status and Gender Role Attitudes: A Comparison of Women and MenCollege Graduates". Gender and Society, 10, (3): 312-329.

Connell, Robert William (1998a). Toplumsal Cinsiyet ve İktidar. Toplum, Kişi ve Cinsel Politika. Çev. C. Soydemir. İstanbul: Ayrıntı Yay.

Connell, Robert William (1998b). "Masculinities And Globalization”. Men And Masculinities 1 (1): 3-23.

Connell, Robert W. \& Wood, Julian (2005). “Globalization and Business Masculinities”. Men and Masculinities, 7, (4): 347-364.

Cournoyer, Robert J. \& Mahalik, James R. (1995). “Cross-Sectional Study of Gender Role Conflict Examining College-Aged and Middle-Aged Men". Journal of Counseling Psychology, 42, (1): 11-19.

Cüceloğlu, Doğan (2006). İnsan ve Davranışı. Psikolojinin Temel Kavramları. İstanbul: Remzi Kitabevi. 15. Bask1.

Çelebi, Nilgün (1990). Kadınlarımızın Cinsiyet Rolü Tutumları. Konya: Sebat Ofset

Dijsktra, Geske \& Plantenga, Janneke (1997) Gender and Economics. A European Perspective, Londra: Routledge.

Durak, Mithat-Durak, E. Şenol vd. (2016). Aklımın Aklı: Psikoloji. Ankara: Nobel Akademi Yayıncilık. 2. Baskı.

Eagly, Alice H. \& Wood, Wendy (1999). "The Origins of Sex differences: Evolution Versus Social Structure". American Psychologist, (54): 408-423.

Eisler, Richard M. \& Blalock, Janice A. (1991). “Masculine Gender Role Stress: Implications For the Assessment of Men". Clinical Psychology Review, 11(1): 45-60.

Ekiz, Durmuş (2017). Bilimsel Araştırma Yöntemleri. Ankara: Anı Yayıncılık. 5.Baskı

Ersoy, Ersan (2009). “Cinsiyet Kültürü İçerisinde Kadın ve Erkek Kimliği”. Fırat Üniversitesi Sosyal Bilimler Dergisi, 19 (2): 209-230.

SEFAD, 2018 (39): 355-372 
Garst,Jennifer \& Bodenhausen, Galen (1997). “Advertising's Effects on Men's Gender Role Attitudes". Sex Roles, 36, (9/10): 551-572.

Gerrig, Richard J. \& Zimbardo, Philip G. (2015). Psikolojiye Giriş Psikoloji ve Yaşam. Çev. G. Sart. Ankara: Nobel Yayınları. 19. Baskı

Good, Glenn. E. \& Dell, Don M. et al. (1989). “Male Role And Gender Role Conflict: Relations to Help Seeking in Men". Journal of Counseling Psychology, 36(3): 295-300.

Gül, Gülşah (2016). Evlilik Biçimleri Açısından Evlilik Uyumu, İlişkilerde Yükleme Tarzlar Ve Psikolojik Dayanıklılık Değģşkenlerinin İncelenmesi. Yüksek lisans tezi. İstanbul: Beykent Üniversitesi Sosyal Bilimler Enstitüsü

Hünler, Olga S. (2002). The Effects Religiousnesson Marital Satisfaction And The Mediator Role Of Perceived Marital Problem Solving Abilities Between Religiousness And Marital Satisfaction Relationship. Yüksek lisans tezi. Ankara: ODTÜ Sosyal Bilimler Enstitüsü

Karakaya, İsmail (2014). Bilimsel Araştırma Yöntemleri. Edit. A. Tanrı̈ğen. Ankara: Anı Yay.

Liao, Tim Futing \& Cai, Yang et al. (1995). "Socialization, Life Situations, And Gender-Role Attitudes Regarding The Family Among White American Women". Sociological Perspectives, 38 (2): 241-260.

Lye, Diane N. \& Waldron, Ingrid (1997). "Attitudes Toward Cohabitation, Family, And Gender Roles: Relationships To Values And Political Ideology". Sociological Perspectives, 40 (2): 199-225.

Mahalik, James R. \& Cournoyer, Robert J. et al. (1998). “Men's Gender Role Conflict And Use of Psychological Defenses". Journal of Counseling Psychology, 45(3): 247-255.

Mensch, Barbara S. \& Ibrahim, Barbara. L. Et al. (2003). "Gender-Role Attitudes among Egyptian Adolescents". Studies in Family Planning, 34 (1): 8-18.

Onaran, Oğuz-Büker, Seçil vd. (1998). Eskişehir'de Erkek Rol ve Tutumlarma İlişkin Alan Araştırması. Eskişehir: Anadolu Üniversitesi Yay.

Patterson, Joan M. \& McCubbin, Hamilton I. (1984). "Gender Roles and Coping". Journal of Marriage and Family, 46 (1): 95-104.

Plotnik, Rod (2007). Psikolojiye Giriş. Çev. T. Geniş. İstanbul: Kaknüs Yay.

Sancar, Serpil (2009). Erkeklik: İmkansiz İktidar. Ailede, Piyasada ve Sokakta Erkekler. İstanbul: Metis Yay.

Sancar, Serpil (2014). Türk Modernleşmesinin Cinsiyeti. Erkekler Devlet, Kadınlar Aile Kurar. İstanbul: İletişim Yay. 3. Baskı

Segal, Lynne (1992). Ağır Çekim. Değişen Erkeklikler Değgişen Erkekler. Çev. V. Ersoy. İstanbul: Ayrintı Yay.

Sönmez, Veysel-Alacapınar, Füsun G. (2017). Örneklendirilmiş Bilimsel Araştırma Yöntemleri. Ankara: Anı Yay. 5. Baskı

Şendil, Gül- Korkut Yeşim (2008). “Evli Çiftlerdeki Çift Uyumu Ve Evlilik Çatışmasının Demografik Özellikler Açısından İncelenmesi", Türk Psikiyatri Dizini. (28): 15-34.

Vefikuluçay, Duygu-Zeyneloğlu, Simge vd. (2007). "Kafkas Üniversitesi Son Sınıf Öğrencilerinin Toplumsal Cinsiyet Rollerine İlişkin Bakış Açıları". Hemşirelik Yüksekokulu Dergisi. 26-38.

Wade, Jay C. (1996). “African American Men's Gender Role Conflict: The Significance of Racial Identity". Sex Roles, 34 (1/2).

Witt, Susan D. (1997). Parental İfluence on Children's Socialization to Gender Roles. Adolescence, San Diego: Libra Publishers.

Zeyneloğlu, Simge-Terzioğlu, Füsun (2011). “Toplumsal Cinsiyet Rolleri Tutum Ölçeğinin Geliştirilmesi ve Psikometrik Özellikleri". Hacettepe Üniversitesi Ĕ̆itim Fakültesi Dergisi. (40): 409-420. 